\title{
Telón de fondo. Paisajes de desierto y alteridad en la fotografía de la Patagonia $(1880-1900)^{1}$
}

\section{Backdrop. Desert and Alterity Landscapes in the Photography of Patagonia (1880-1900)}

\author{
Carlos Masotta \\ CONICET-Universidad de Buenos Aires. Argentina \\ cmasott@hotmail.com
}

Resumen - El paisaje patagónico construido por la fotografía del período 18801900 fue un marco en donde se llevó a cabo el ingreso civilizatorio. Luego de una caracterización general del problema (el paisaje desierto como «escenificación de ausencia») en torno a los primeros álbumes de Estado sobre la región, centro el análisis de este artículo en dos obras que describieron el Territorio de Chubut: Viaje a la Patagonia Austral (1886) del Coronel Luis Fontana y la Excursión a la Patagonia y a los Andes de Aarón Anchorena (1902). Entre ellas puede observarse la articulación de una mirada militar y civil donde el paisaje fotográfico del desierto se involucra en la toma material y simbólica del territorio como un escenario donde se «naturaliza» la actuación de un ingreso civilizatorio y la desaparición de los pueblos indígenas.

Palabras clave: paisaje, Patagonia, fotografía, indígenas, alteridad.

Abstract - The Patagonian landscape built up by photography during the 18801900 periods was the framework in which the civilizing entrance took action. After a general description of the problem (the deserted landscape as the staging of absence) about the first State's albums on the region, I focus the analysis on two works describing the Territory of Chubut: Viaje a la Patagonia Austral (Trip to Southern Patagonia) by Coronel Luis Fontana (1886) and Excursión a la Patagonia y a los Andes (Tour to Patagonia and the Andes), de Aaron Anchorena (1902). The articulation of a military and civil glance can be observed between them, where the photographic landscape of the desert is involved in the material and symbolic shot of the territory as a stage where the acting of a civilizing entrance and the disappearance of the indigenous peoples is naturalized.

Keywords: landscape, Patagonia, photography, indigenous, alterity.

1 El presente trabajo se inscribe en el proyecto «Fotografía, Memoria y Archivos. Poética y política de la mirada nacionalitaria» de la Universidad de Buenos Aires (Ubacyt S445). En él retomo y doy continuidad a escritos anteriores (Masotta, 2006 y 2009). 


\section{INTRODUCCIÓN. PAISAJE Y AUSENCIA}

En la evocación retrospectiva del capítulo final de su diario de viaje alrededor del mundo, Charles Darwin dedicó al paisaje patagónico extensos párrafos. En ellos es posible encontrar la fascinación que la contemplación de la naturaleza provocaba en el naturalista. Pero, a pesar de lo diverso de la geografía recorrida y de su experiencia viajera, nada muy novedoso aparece allí. Darwin aplica las coordenadas clásicas de lo «sublime», lo «bello» y lo "pintoresco», propuestas ya para la educación de la mirada de turistas, viajeros y pintores europeos desde el siglo anterior. Y de ese preciso encuadre hizo surgir, como un enigma, «el desierto».

Entre los paisajes que más hondamente se han grabado en mi mente, ninguno aventaja en sublimidad al de las primitivas selvas vírgenes no alteradas por la mano del hombre; sean estas las del Brasil, donde domina el poder de la Vida, sean las de Tierra del Fuego, donde prevalece la Muerte y la Disolución [...].

Cuando evoco los recuerdos del pasado, las llanuras de la Patagonia acuden frecuentemente a mi memoria. Y, sin embargo, todos los viajeros están acordes en afirmar que son miserables desiertos. No puede atribuírseles casi más que caracteres negativos; en efecto no se encuentran allí ni casas, ni agua, ni árboles, ni montañas; apenas si se ven algunos arbustos achaparrados. ¿Por qué, entonces estos desiertos - y no soy el único que ha experimentado estos sentimientos- han causado en mí tan profunda impresión? No puedo analizar esos sentimientos, pero deben provenir del libre impulso dado a la imaginación. Las llanuras de la Patagonia son sin límite; apenas se las puede franquear y, por lo tanto, desconocidas; llevan el sello de haber permanecido como están hoy durante larguísimas edades, y parece que no ha de haber límite en su duración futura [...].

Réstame señalar desde el punto de vista pintoresco, el panorama que se desarrolla a los pies del viajero llegado a la cima de una alta montaña. En ciertos aspectos, el cuadro no es verdaderamente bello pero el recuerdo de él dura largo tiempo. Cuando por ejemplo, se ha llegado a la cumbre más alta de la Cordillera y se mira en torno, queda uno estupefacto, desprovisto de lo que representa la vista en detalle, ante las dimensiones colosales de las masas que le rodean (Darwin, 2002: 506).

Casi doscientos años después podemos contestar aquí la pregunta de Darwin de una manera inversa. No es el desierto el que afecta los sentimientos y la imaginación. Es esta última (ahora histórica y social) la que, involucrada con esos sentimientos, produce el paisaje desierto sobre la Patagonia. Es decir, una geografía imaginaria (Said, 1990).

En su evaluación de la relación entre la naturaleza y la cultura, el paisaje puede considerarse como la escenificación de una ausencia. La de quien lo identifica, lo contempla o lo produce. En este sentido existe el caso paradójico del paisaje del desierto, la escena de un espacio inhabitado donde, no obstante, se encontrarían ambas ausencias en ese esfuerzo por mantenerse «en bambalinas». Allí, la mirada paisajística descubre su efecto fundacional y su impulso geopolítico en la determinación de un límite que es una frontera social narrada visualmente. Su preocupación por la distinción entre la naturaleza y cultura también opera en una diferenciación entre los hombres. El paisaje del desierto es un encuadre, que expulsa a los hombres en la visión de una tierra virgen y arcaica - pero nueva- ante quien así la describe. En el proceso de colonización del espacio americano 
ese paisaje fue una lente hegemónica en la caracterización de su territorio y de sus habitantes (Pratt, 1997; Cosgrove, 2002; Penhos, 2005).

En este trabajo abordo el lugar de la reproducción de esos presupuestos en la fotografía del paisaje patagónico. Me centraré particularmente en el período de nacionalización de la región, es decir, de su incorporación por los poderes del Estado Nacional y el inmediato proceso posterior de colonización civil entre 1880 y 1900 , aproximadamente.

Como ha sugerido Adolfo Prieto (1996), las narrativas de los viajeros ingleses de principios del siglo XIX fueron la plataforma desde donde la escritura argentina observó y describió el territorio nacional. Propongo aquí que un fenómeno de similares características se desarrolló mediante la incorporación de la primera fotografía al caso patagónico. Con todo, se presentan notables diferencias relacionadas, por una parte, a la contemporaneidad de esa fotografía con las políticas de exterminio indígena que se desarrollaron en la toma estatal y civil de ese espacio, y por otra, al carácter nacionalista y civilizador que se imprimió en el territorio por medio de este dispositivo.

En resumen, propongo un abordaje de esas imágenes como un eslabón más en la cadena de operaciones de construcción de alteridad que caracterizó al período y que aún tiene efectos. La importancia del paisaje en ese proceso reside en que la alterización se desarrolla en forma indirecta o disimulada a través de una mirada «neutral» de la naturaleza. En ese lapso, la toma del territorio patagónico fue parte de la modernización del Estado y de la sociedad civil. La fotografía como nuevo recurso de registro se involucró en ese proceso al tiempo que se fundaba a sí misma. La noción de paisaje operó en este tipo de préstamos e intercambios entre la mensura del espacio y la de la vida de los hombres. Para el análisis del paisaje en esta perspectiva sigo las sugerencias al respecto de los trabajos de Simón Schama (1996), Chris Fitter (1995) y Eric Hirsch (1995), y Graciela Silvestri y Fernando Aliata (2001) y Denis Cosgrove (2002).

\section{ESCALAS Y ALTERIDADES}

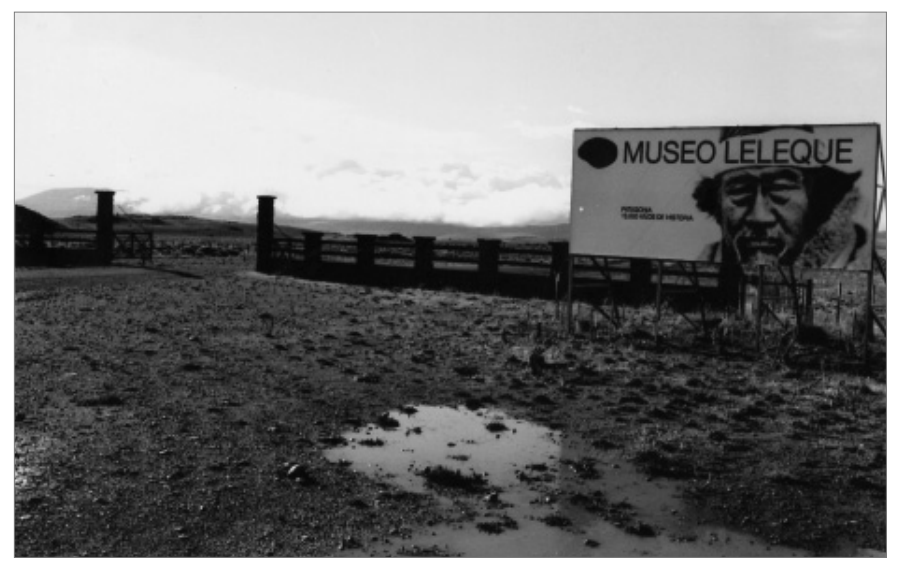

1. Epígrafe: Entrada al Museo Leleque (Provincia de Chubut, Argentina). Fotografía: Carlos Masotta. 
Un viajero desprevenido que se interne en la Patagonia por la ruta 40 hacia los valles precordilleranos de la provincia de Chubut, será sorprendido por la mirada triste de un viejo indio tehuelche colocada en un gran cartel que convoca a ingresar a un museo inaugurado a fines del pasado milenio. Sin embargo, la gigantografía parece pequeña, pues no logra contrarrestar el efecto del amplio escenario que la subsume.

El museo se instaló en lo que fue el antiguo casco de la estancia Leleque, el latifundio más extenso de la región fundado en 1889. Está, hacia el oeste, a los pies de la cordillera $\mathrm{y}$, hacia el este, de cara a la inmensidad de la meseta patagónica que se pierde en un lejano y brumoso horizonte (lámina 1).

El lugar es extraño para un museo. Hacia fines del siglo XIX fue estratégico para el repliegue de los últimos caciques rebeldes que persiguió y capturó el Ejército Argentino en 1884, durante la llamada "Conquista del Desierto». Poco después, la instalación inmediata del edificio de la administración de la estancia respondió, por supuesto, a la estrategia de maximizar la explotación de esas tierras, del ganado y de los hombres. Pero hoy, como museo, su actividad ya no es económica sino estética. Y esa conversión es extraña allí, solitaria y alejada del medio urbano, tradicional para esas instituciones fundadas en la exhibición y en una pedagogía de la mirada con vocación pública y masiva. No se trata de un «museo de sitio» que justifique su emplazamiento alejado en alguna ruina o relato específicamente localizado en el lugar. La temática del Museo Leleque no es el pasado de la explotación ovina o el de la estancia que lo cobija sino: «Patagonia. 13000 años de historia». El eslogan, en su magnificación temporal, coincide con la ampliación del retrato del hombre tehuelche.

La hipérbole no es algo nuevo para una región caracterizada por su propio topónimo, ya desde el siglo XVI, como una tierra de gigantes patagones (Livon-Grosman, 2003). La operación metonímica entre sus «naturales» habitantes y la «naturaleza» del espacio, acompañó la constatación europea de la existencia de un continente mayor que la misma Europa al Oeste del Atlántico. El viaje de Magallanes se encontró con esos gigantes justo en el límite de ese continente que parecía no cesar de avanzar hacia el sur.

Ese rostro tehuelche, colocado sobre el paisaje patagónico como la esfinge en el desierto del Antiguo Egipto, nos muestra que tal hipérbole étnico-territorial ha llegado hasta nuestros días y que el desierto sigue siendo un escenario propicio para esa actuación.

Las políticas del Estado Argentino dirigidas contra los indios de la Patagonia, en el último tercio del siglo XIX, tuvieron un especial componente de exhibicionismo y espectacularización. El primer acto se desarrolló sobre el mismo territorio y fracasó. Fue la «Zanja de Alsina» iniciada en 1876, también conocida como «Zanja Nacional», que pretendió hacer un corte en el territorio para detener los ataques indígenas sobre la avanzada de la colonización agrícola de la pampa cavando una línea de 600 kilómetros jalonada por fortines.

En recuerdo de la Muralla China o del foso medieval con el que frecuentemente se la comparó, pareció un anacronismo que se enfrentaba a otro: los indios (Blengino, 2005). La criticada e inoperante Zanja dejó paso a una política ofensiva, pero el proyecto de una gran construcción en la frontera con el desierto, movilizando a cientos de hombres, millonarios recursos e ingenieros europeos, fue un gesto grandilocuente que, de alguna manera, se mantendría durante la nueva etapa. En ésta la fotografía tendrá un rol destacado. 
El segundo acto se realizó tres años después de la Zanja y fue mucho más cuidadoso en su preparación, pues ahora sabía que, si bien las acciones debían ejecutarse en la Patagonia, la actuación se representaría en Buenos Aires. Se lo llamó «La Conquista del Desierto», otro anacronismo, pero esta vez mucho más efectivo. Denotaba el carácter progresivo de la acción (recuérdese el auge del positivismo y de la ideología del progreso), abrevaba en la "Conquista de América» un tropo mucho más efectivo y afectivo para el caso Argentino que la Muralla China y, finalmente, resolvía el enigma de un paisaje que no había dejado de torturar la conciencia de las clases dirigentes: el desierto. ${ }^{2}$

La «Conquista del Desierto» se denominó a una avanzada militar, en un principio dirigida por el General Julio Roca, desarrollada entre los años 1879 y 1886. Capturó y relocalizó a los grupos indígenas de la Patagonia hasta la provincia de Chubut. El tipo de uso que se hizo de la fotografía en esos movimientos de tropas puso de manifiesto el interés por la exhibición de la operación, interés que no fue un aspecto suplementario sino un elemento constitutivo de la misma «Conquista». En este sentido, la incorporación a la expedición de Antonio Pozzo (fotógrafo personal del General Roca) y la producción de sus voluminosos álbumes son elocuentes. Con todo, las escenas posadas de rituales propios de las formaciones militares en el territorio y los usos de esas fotos por la pintura histórica unos años después, señalan los diversos caminos que encontraron en esa fotografía su conexión con el desierto.

Retomo aquí algunas consideraciones de un trabajo anterior (Masotta, 2009). Las fotos de Pozzo reúnen retratos del grupo de autoridades militares con panorámicas, en muchas de las cuales es evidente el «error» del fotógrafo al evaluar la relación entre perspectiva y proporciones. En ellas se crea un efecto de vacío o de un territorio desbordado por el espacio: el desierto como desproporción.

El fotógrafo se aleja de los sujetos. Cuanta más distancia toma de ellos mayor es la porción de horizonte retratable y, en esa dialéctica, gana el primero. Sobre ese territorio los hombres son empequeñecidos, parecen perdidos y sin rumbo.

En la serie de fotos que conformó un álbum de dos tomos, el vacío del territorio, además de su magnificencia, se hace notar por un contraste con las líneas regulares de las formaciones militares, los grupos de indígenas cautivos, los trazados de agrimensura de pueblos. En la estepa no hay orientación (no hay caminos ni marcas) y es la avanzada de la civilización la que impone el orden con sus señales características donde no las hay. El álbum de Pozzo realiza ese recorrido: el Ejército se interna en el desorden para regresar al centro. Su última foto muestra la plaza de la ciudad de Patagones con una réplica de la Pirámide de $\mathrm{Mayo}^{3}$. Antes, otra toma muestra un «Arco del triunfo» preparado para el desfile de los militares.

2 La inmensa extensión del país que está en sus extremos, es enteramente despoblada [...]. El mal que aqueja a la República Argentina es la extensión: el desierto la rodea por todas partes, y se le insinúa en las entrañas; la soledad, el despoblado sin ninguna habitación humana, son, por lo general los límites incuestionables entre una y otras provincias. Allí, la inmensidad por todas partes: inmensa la llanura, inmensos los bosques, inmensos los ríos, el horizonte siempre incierto, siempre confundiéndose con la tierra, entre celajes y vapores tenues, que no dejan en la lejana perspectiva, señalar el punto en que el mundo acaba y principia el cielo. Al sur y al norte acechando los salvajes, que aguardan las noches de luna para caer, cual enjambre de hienas [...] sobre las poblaciones indefensas. (Sarmiento, 1967 [1845]: 22-3).

3 La «Pirámide de Mayo» fue el primer monumento erigido por el Estado Argentino y ocupa el centro simbólico y político de la Argentina en la ciudad de Buenos Aires. 
La fotografía se suma así a la forma narrativa del viaje que caracterizaba las descripciones del territorio hasta esa fecha. Es el ojo del veedor (Pratt, 1997), que al desplazarse desde el centro hacia la periferia para volver a él, recrea una estructura panóptica presente también en la preeminencia de la toma panorámica de las fotografías.

La «toma» fotográfica del desierto (Tell, 2001) no es una foto del territorio. Es el Estado fotografiándose a sí mismo atravesando el territorio. El Estado se escenifica allí y hace del territorio una pose dócil a sus objetivos. En consecuencia, las fotografías son una voz con que el Estado hace hablar al territorio de su soledad, de su disponibilidad y de su orfandad ante la llegada triunfal que lo redime.

El acto fotográfico quedó documentado en las mismas imágenes en las que Pozzo incluyó en el encuadre la sombra de su cámara junto a la de su ayudante y a la suya propia. No fue simplemente un ejercicio de registro sino parte del ritual de ingreso y toma del territorio.

Con estas fotografías el Estado comienza a producir una mirada panorámica. Por su respeto a la línea del horizonte, la mayoría de las fotos de los álbumes se suceden como las partes de una única toma panorámica que recrearía la visión panóptica del Estado sobre su dominio.

El álbum de Encina y E. Moreno, que replica la experiencia de Pozzo en el avance del Ejército hacia la cordillera unos años después, se titulará Panoramas de los Andes. Ese álbum fue tratado por Julio Vezub (2002). Solo agregaré aquí que en dicho álbum el tratamiento fotográfico del paisaje, en relación con la obra de Pozzo, profundiza la ausencia humana en función de la toma de la naturaleza desierta. En Pozzo solo 3 de sus 53 tomas retratan el espacio sin intervención de la escena militar con o sin indígenas. En el álbum de Encina y Moreno más de la tercera parte de sus 180 fotos está dedicada exclusivamente a paisajes desiertos.

Este desplazamiento de las tomas, de la acción de los sujetos hacia las del paisaje natural, puede verse como un capítulo singular en el desarrollo de la iconografía fotográfica de la Patagonia. El paisaje allí ya no es soporte ni de la escena de la derrota indígena (indios prisioneros, indios soldados, bautizados, a los pies de los sacerdotes, cementerios profanados), ni de la conquista y toma militar (poses ecuestres, formaciones solemnes, cruces de ríos). El encuadre fotográfico ha desplazado a los blancos y a los indios, tampoco aparecen sus marcas (chozas, caballos, campamentos). Comienza allí el relato mudo de la naturaleza, o mejor dicho, el relato mudo de una visión de la naturaleza que aun en el molde de la cartografía militar se acerca a la de una contemplación. Ahora, con la desaparición de los hombres, la naturaleza impone su propia escala. ${ }^{4}$

Esos gruesos álbumes $(43 \times 51 \mathrm{~cm}$ el de Pozzo; 31 x $40 \mathrm{~cm}$. en de Moreno y Encina) fueron usados por al pintor Manuel Blanes para concretar en 1896 el cuadro «La

\footnotetext{
«En el caso norpatagónico, el antagonismo entre un ámbito natural, virginal y la intrusión festejada de la civilización en el mismo tuvo una persistente inscripción en el álbum. [Sin embargo, el] País de las Manzanas no era hacia 1883 un espacio socialmente vacío. Constituía en cambio una región que había sido literalmente vaciada de población en los años inmediatamente anteriores a la mensura en Encina y Moreno. Valentín Sayhueque, el principal jefe indígena de ese territorio, había trasladado sus campamentos del Río Caleufú con dirección sur, hacia el interior de la meseta patagónica, ante el asedio de las tropas dirigidas por Lorenzo Vintter en 1881. Otros caciques y familias..., buscaron refugio en el interior de la cordillera o directamente del otro lado de los Andes. Las fotos del álbum son un registro de ese abandono abrupto del territorio, al tiempo que constituyen una prueba de fe sobre la capacidad del Estado nacional para llenar en lo inmediato el vacío civilizatorio» (Vezub, 2002: 28).
} 
Conquista del Desierto» que le encargara el entonces presidente de la República Julio A. Roca. Por ejemplo, de la fotografía $n^{\circ} 2$ del álbum de Pozzo que muestra al «Grupo de Jefes» de pie frente a la tienda de campaña, el pintor tomó los rostros del Roca, del Coronel Villegas y del Coronel García para componer sus figuras ecuestres en el cuadro; la formación de caballos en general reitera la distribución presente en distintas tomas de ambos álbumes. La obra de Blanes también llevó el título elocuente de la reflexividad depositada en la mirada: "La revista del Río Negro». En ella se recreó el acto patrio del amanecer del 25 de mayo realizado por la avanzada de Roca en 1879 en las costas del Ríos Negro. Sin embargo, el cuadro incorporó a todas las figuras militares e incluso civiles que participaron el los años posteriores y que no habían estado en aquel acto. Así la tela de Blanes realiza como una apoteosis de la «Conquista del Desierto» en general (Amigo, 1994). Una versión pictórica de un mito de origen: el comienzo patriótico y civilizador de la toma de la Patagonia después de la expulsión de los indígenas.

En la tela la mayor parte de la escena reproducida muestra la formación militar y el paisaje natural casi oculto solo sirve de soporte confirmatorio de la versión iconográfica de la ocupación territorial. No obstante, en la actitud de los militares frente al entorno se encuentra algo de ese pasaje, entre una mirada escrutadora de mensura territorial y otra de contemplación reflexiva. Los caballos del grupo ecuestre, están dispuestos en una ordenada irregularidad, sin embargo, los militares posan con sus sables desenfundados y con la vista puesta atenta en el horizonte. A diferencia de ellos, Roca orienta su rostro levemente hacia el suelo frunciendo el ceño. Con su mano izquierda posa un binocular sobre su montura. Ya ha mirado "a lo lejos", ahora reflexiona. En el extremo izquierdo de la tela un grupo de indios sometidos junto a una cautiva blanca con un niño en brazos y un sacerdote forman una composición interrumpida por el marco. Precisamente fuera de cuadro y hacia donde se dirigen las miradas está el sentido de la pintura. Esa dirección agrega un componente geopolítico a la composición. Las largas sombras delatan la orientación hacia el sur oeste de la formación militar. El territorio, ahora desierto (se trata de la consecución de la «Conquista»), solo encuentra el límite de la frontera con Chile recién establecida en la región (1881).

La «Conquista del Desierto» fue hecha dentro y para el Museo Histórico Nacional. Es el cuadro de mayores proporciones de la pintura de la Argentina (4 x 11 metros). Cuando en 1889 se inauguró el museo, aquel evento apareció como el punto de llegada de la saga nacional interpretada ahora en su versión oficial como un proceso civilizatorio que tuvo al Ejército como protagonista y al desierto como escenario.

\section{FENOMENOLOGÍA DE LA PATRIA}

Si el cartel del museo Leleque coloca un retrato indígena sobre el «desierto» patagónico, las primeras fotografías de la región hicieron un recorrido opuesto: fotografiaron el desierto para colocarlo en la ciudad. Los viajeros, científicos y militares que emprendían el viaje patagónico luego escribían su memoria con grabados y fotos que el Estado o la prensa editaban y difundían. 
En esas publicaciones la polarización entre las formas retrato y paisaje son marcadas en beneficio del segundo. En la visión del Estado y de los militares que llevaron adelante la "Conquista del Desierto» la población aborigen no era considerada parte de la nación y en consecuencia su representación fotográfica sufrió una suerte de desprecio icnográfico coincidente con lo que suele denominarse proceso de invisibilización. Las funciones de racialización que el retrato indígena ocupó en otros países como Perú (Poole, 2000), en Argentina y en particular en lo referente a la Patagonia, fue ocupado por el paisaje. En él, en sus propias formas desiertas, se expresaba la patria.

Una de las primeras descripciones más o menos sistemáticas de esa zona del Chubut fue publicada en 1885. Ese año el gobierno nacional ordenó la impresión de mil ejemplares de Viaje de exploración a la Patagonia Austral, "a fin de fomentar su población», según la resolución firmada por el propio Presidente de la República. Su autor, el Teniente Coronel Luis Fontana, recuerda en ese texto, de una forma singular, el momento en que recibió la orden de marchar a la Patagonia mientras estaba en el Chaco, en el norte del país de campaña contra los indígenas.

Allí, a la sombra del bosque, viendo correr el agua rojiza como la sangre, haciendo construir un fortín y soñando con la grandeza de mi patria, hacía pasar la mente por sus ríos, los más extensos del mundo, por sus bosques, sólo accesibles al hombre intrépido, subiendo a sus montañas escarpadas y cubiertas de nieve [...], o bien corriendo las verdes llanuras sin límites, evocaba en cada una de esas extrañas formaciones de la naturaleza, siempre admirable y portentosa, la imagen soñada de la patria, que surgía resplandeciente en el llano, en la montaña, en el río, en los gloriosos años de nuestra historia o en el infinito de nuestro porvenir.

[...] Después, como una realidad del presente, estaba allí a mis pies, el indio, tan indómito y salvaje como el día en que el ilustre genovés descubrió el nuevo continente [...] Pero a su lado, en vez del conquistador aventurero [...] se levantaba simpático y airoso el soldado argentino... (1976 [1885]: 28).

Como puede notarse, en esta retórica patriótica y civilizatoria el militar es, antes que un guerrero, un «soldado del paisaje» donde él mismo se escenifica junto al indio. Se encuentra en él y en él se inspira descubriendo allí a la patria. "Mi patria», "sus ríos», "sus bosques», «sus montañas». En la naturaleza del paisaje militar se consolida un proceso de adscripción, pertenencia y posesión. La «extensión» del territorio que fue interpretada por Sarmiento como una maldición, luego de la "Conquista del Desierto", se ha trocado en «grandeza».

Nótese también que en el relato de Fontana, su reflexión se presenta como previa a la experiencia patagónica e incumbe a todo el territorio en general. Luego, y ya en su tránsito por el Chubut, tendrá que evocar con más precisión esa «imagen de la patria», ahora sobre un territorio singular. Para ello la fotografía fue un elemento de especial utilidad, no solo en el reconocimiento del territorio, sino en la construcción de sentidos patrióticos sobre él. Señalaré a continuación algunos de estos sentidos.

Por una razón curiosísima dimos a este punto el nombre de Valle Alsina y se sacaron de él tres vistas fotográficas.

Era el día doce de noviembre y nuestro reloj marcaba las ocho de la noche. Nuestro campamento estaba al borde de tres cerros cortados verticalmente, y la sombra que proyectaba el 
primero de estos sobre el muro vertical del segundo, representaba con parecido perfecto y en proporciones gigantescas el perfil de la cara del doctor Don Adolfo Alsina. El ingeniero Katterfeld fue quien hizo tan curiosa observación, pero al participar a los demás este hecho tan casual, reservó su opinión llamando sólo la atención acerca del reflejo de la faz humana que se veía; pero todos los que conocieron la vida del ilustre argentino reconocieron inmediatamente su silueta varonil trazada por el acaso en aquel valle tan distante e ignorado.

Si mal no recordamos, un fenómeno de esta naturaleza ocurre en las islas San Vicente, simulando el perfil de una sierra en el azul del cielo el rostro y el cuerpo del general Wellington dormido.

A la mañana siguiente con sol ya alto, a eso de las ocho, volvimos a ver la sombra del noble caudillo, que por esta coincidencia dio nombre al valle (64).

Más adelante, después de unos días de marcha, la expedición encuentra un nuevo motivo de registro fotográfico, ya cercano a los valles de la precordillera.

Después de esto viene el valle que hemos denominado «de las ruinas», por el aspecto ruinoso que simula en sus caprichos fortuitos la formación arenisca, a tal punto que la imaginación no encuentra límites al asombro.

Puede V. E. destinar un momento de observación a las vistas fotográficas que las representan, en parte, y participará sin duda de nuestra opinión.

Uno pasea por este valle con la mirada absorta, contemplando monumentos naturales, y llega un instante en que es tan perfecta la ilusión que se llega a creer que la mano del hombre ha intervenido y que están alineados con arte; se ven calles, una colosal estatua sobre un pedestal, palacios derruidos, la cara de una egipcia, el perfil de un viejo que ríe; en fin nada carece de representación gráfica; por un momento nos creíamos transportados a Egipto, porque el valle en que estábamos parecía haber sido el asiento de una gran ciudad en el pasado (69).

El desierto se nacionaliza en la imaginación toponímica del explorador buscando y encontrando en las formas naturales los símbolos de la patria y la civilización. La operación articula en la toponimia del paisaje el acto de dominio territorial, pero al hacerlo fundado en sus propias formas se juega con la idea de que es la nación y la civilización misma la que en ellas emerge. Y en ese juego la fotografía genera el mejor efecto de verosimilitud. El antecedente clásico en este sentido es el bautismo del lago «Argentino» por el naturalista Francisco Moreno, diez años antes que Fontana.

Dicha operación ya había sido desarrollada extensamente por Francisco Moreno en sus viajes patagónicos en la década anterior (1879) y repetida por todos los exploradores del período. Fontana ha leído esos trabajos con atención y su informe quiere profundizar y «corregir errores».

El paisaje desierto, antes irredento pero ahora la patria misma, guarda un principio latente. Se trata de la población que hacia finales del siglo XIX y principios del XX era concebida por la política inmigratoria. En este sentido, el desierto del paisaje patagónico habla el lenguaje de un proyecto de colonización europea y occidental (que no se realizará). El paisaje fue una ilustración de esa utopía racial y el soporte de una alteridad imaginada que se realizaría en un futuro donde la "grandeza" del paisaje coincidiría con la de su poblamiento. 


\section{LA CACERÍA}

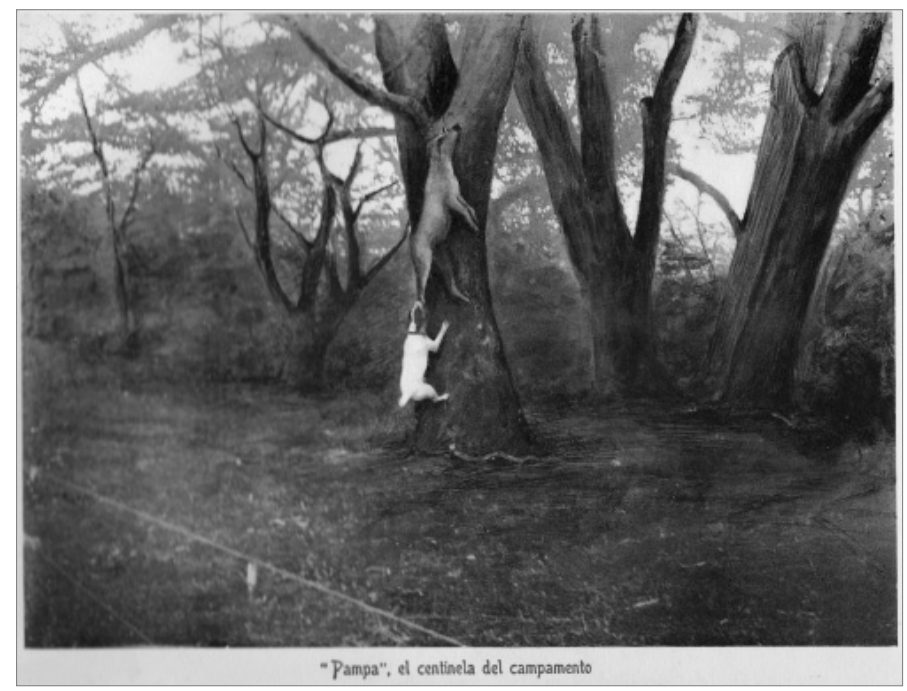

2. «Pampa〉 centinela del campamento». Excursión a la Patagonia y a los Andes (1902) de Aarón Anchorena.

Entre la ciencia natural y la política militar, en la toma del espacio patagónico, el paisaje desierto fue objeto también de una mirada que, aunque relacionada con esas dos experiencias, se fundaba en un proceso de percepción burguesa desprovista de los imperativos positivistas y patrióticos. Entre 1870 y 1900 aproximadamente, las experiencias de los hacedores de esos paisajes eran «híbridas». El militar era naturalista, el naturalista era viajero y todos escribían con participación en la política nacional como producto de su posición de clase burguesa y letrada. El paisaje no fue ajeno a la cultura de esa clase, fue un capítulo especial de su educación estética y del afianzamiento de la idea de individuo. Al respecto, el antecedente más notable es el lugar del paisaje en la pintura del romanticismo como ingreso a la meditación sobre el lugar del individuo ante el destino azaroso señalado por las fuerzas de la naturaleza.

Después de Darwin, la forma militarizada del ingreso tardío de la Patagonia al dominio del Estado Nacional y el retardo en su colonización no provocaron visiones existenciales sobre su paisaje, aunque sí se desarrolló un tipo de mirada vicaria de aquella visiones. Días de ocio en la Patagonia («Idle days in Patagonia») publicado por Enrique Hudson en 1893 es un índice literario elocuente:

¡Por fin en la Patagonia! Cuantas veces lo había imaginado, deseando ardientemente visitar la soledad agreste, la lejanía serena con su voz primitiva y desolada, sin huellas humanas, tan lejos de la civilización! Allí se extendía ante mí el desierto virgen que tan extrañas sensaciones despierta en nosotros; la antigua vivienda de gigantes, cuyas pisadas, descubiertas sobre la costa, asombraron a Magallanes... (1956 [1893]: 23).

Hudson relata el viaje que había realizado entre 1870 y 1871 como naturalista con interés especial en la ornitología. Pero su texto se mueve de la ciencia a la literatura, la poesía y la reflexión íntima. Ernesto Livon Grosman afirma que con él se abre una nueva 
narrativa sobre la región: «Lo que Hudson ofrece es un desplazamiento de la esfera física a la sociológica, del relevamiento geográfico o biológico a la interiorización del paisaje» (2003: 183).

La Patagonia es ya un paisaje deseado («iPor fin...!»), incluso «ardientemente». Su exploración no solo está motivada por intereses geopolíticos o científicos. La visión panorámica y paisajística permite un paso o asociación metonímica en la construcción imaginaria de la región como una unidad. Esa construcción es evaluada en el contraste desierto-ciudad, y en ella la Patagonia es adoptada como una línea de fuga de la experiencia urbana.

Hudson se detiene en el caso de un hombre obligado a abandonar Buenos Aires y vivir en la región por una enfermedad pulmonar.

Me dijo que había logrado un buen pasar a costa de un enorme sacrificio, porque le resultaba imposible acomodarse a una existencia tan ruda, ya que era esencialmente un producto de la civilización, un hombre del pavimento, cuyo placer residía en la sociedad, en los diarios, teatros y cafés donde uno halla a sus amigos al anochecer y juega una entretenida partida de dominó. [...] estas cosas que él tanto valoraba, no significaban nada para mí... [...] si por casualidad alguno de mis lectores, tiene otros ideales, siente que la gloria y el misterio de la existencia anegan su alma con sus problemas e incógnitas [...], a uno en estas condiciones, repito, diría: Pruebe la Patagonia (117).

Entre el viaje de Hudson y la publicación del libro se había consumado la "Conquista del Desierto» y el tono de su escritura ociosa parece más cercano a la fecha de publicación que a la de aquella experiencia realizada en épocas de malones. Por otra parte, Hudson escribió su libro en Londres.

En 1902 se publicó una obra que puede considerarse una consumación fotográfica de esa mirada prototurística del paisaje patagónico: Excursión a la Patagonia y a los Andes, de Aarón Anchorena. Este último será constituido en el escenario de una escena singular: la cacería deportiva.

Con formato panorámico, tapas rojas y títulos dorados, llenos de arabescos, en «Excursión a la Patagonia...» la región se ha abierto al viaje de un dandy. En su primera foto, Anchorena posa en la cubierta del vapor «Chubut», que parte de Buenos Aires, de traje y corbata con zapatos especialmente brillantes y, con un gesto casi femenino, sacándose sus guantes. Luego vestirá riguroso traje de explorador, con botas, y portará un binocular en la charretera. Las dos fotos siguientes lo muestran junto a sus acompañantes frente a un gran cañón en el puerto de Bahía Blanca. En la última fotografía («de regreso») aparece el grupo nuevamente con ropas urbanas en un andén junto a al tren que los llevará a Buenos Aires, desde la estación Confluencia en Neuquén. La tecnología de transporte enmarcando la narración es algo novedoso. Los exploradores anteriores, si bien hicieron uso de ella no se detuvieron en su descripción, más aún, la ocultaron. El mismo Roca en su campaña de 1879 comenzó su viaje al sur en ferrocarril. Ya no usa el término «exploración» sino «excursión». Y en relación a lo que dijimos arriba, esa mención urbana (la ropa y la técnica) marca ahora el viaje a la Patagonia como un paréntesis a la vida urbana de donde se sale y adonde se regresa.

La obra de Anchorena es un álbum fotográfico. Consiste en un texto introductorio de 9 páginas y más de 150 fotografías ordenadas cronológicamente en relación al avance del viaje. Anchorena replicó, quince años después, un itinerario semejante al que realizara 
Luis Fontana remontando el río Chubut hasta la cordillera, para continuar luego con otros recorridos extendiendo su regreso hacia el norte hasta el lago Nahuel Huapi.

Al igual que Hudson, Anchorena expone el deseo de conocer el lugar como el objetivo del viaje.

Deseaba conocer aquellas comarcas de las que sólo tenía noticias por la lectura de algunas crónicas de viaje y de las descripciones publicadas por el perito doctor Moreno, uno de los primeros exploradores y tal vez quien conoce mejor aquella hermosa región que forma parte importante del suelo argentino y que es apenas conocida por un número escaso de viajeros, o cuando no solamente por las últimas reliquias que aún subsisten de las razas primitivas que se asimilan a la blanca conquistadora o que se extinguen gradualmente por el vicio, el aislamiento o la miseria (3).

Anchorena es pródigo en su retórica de la desaparición indígena cuando periodiza entre los «primeros exploradores» y los últimos indígenas («primitivas»; «últimas reliquias»; «subsisten», «extinguen»). Con esa retórica los indígenas son incorporados en el territorio al que va a ingresar el autor.

Como el objetivo principal del viaje es la cacería deportiva, en las imágenes ésta aparece como uno de los tópicos centrales. El libro reúne fotografías de escenas del grupo en diferentes alternativas del viaje y abundantes paisajes (incluso con panorámicas desplegables), de animales muertos por la cacería, tomas etnográficas de grupos de indígenas, y algunas familias de colonos. En el texto del "álbum folleto», como lo llama el autor, se describe el orden de las fotos, el objetivo del viaje y algunas alternativas del itinerario.

Tuve la satisfacción de hacer el viaje con dos excelentes compañeros: el señor Carlos Llavallol «chasseur hors ligne» y el doctor Carlos Lamarca.

En calidad de personal iban Louis Boccard, ex empleado como preparador anatómico del Museo de la Plata; Constantino Ambriossioni, de oficio cazador, lleva, según él, el record de los muchos leones y panteras que ha cazado en el centro de África. Telmo Braga fotógrafo.

Llevaba dos perros galgos amaestrados que ya habían andado por la Patagonia, en la comisión de límites, un pointer de caza y el Pampa, un champion fox terrier que me acompaña desde hace años en todos mis viajes y que fue fiel centinela del campamento (3 y 4).

El autor tuvo un cuidado particular al ordenar el relato de acuerdo a la secuencia del viaje. En el texto introductorio, a medida que se narra el avance de la expedición, se remite al lector al número y las «figuras» correspondientes a lo narrado, con anotaciones en el margen de la página a modo de instrucciones de uso.

...he seguido el orden de tiempo de manera que si un lector curioso desea viajar mentalmente por los Andes va a encontrar los paisajes aquí como los encontré allí. Y he pensado que tal forma es la mejor pues la naturaleza no agrupa sus manifestaciones en capítulos homogéneos (3).

En la concepción naturalista que confunde el paisaje con la naturaleza, la fotografía es ubicada como un medio de transmisión fiel de su imagen. La organización en secuencias fotográficas responde al recorrido realizado, sin la interrupción de la separación en capítulos. Como el formato panorámico, solo pautado por los epígrafes, permite acercar la obra a la visión de la cinematografía muda del período. Por su parte, "Aquí» y "allí» describen la perspectiva metropolitana del álbum. En resumen, el paisaje fotográfico 
permite un efecto de realidad separado de la acción de los sujetos que solo lo observan, lo transitan, posan en él, pero no lo afectan. Ese efecto de realidad permite la afirmación de la objetividad en la transmisión de imágenes de la naturaleza separada de la actividad de los hombres que "allí» la «encuentran». Nuevamente el viajero occidental se muestra como un «veedor» (Pratt) que usa esa visión objetiva para poner en un segundo plano sus actividades e intereses en relación con la naturaleza que atraviesa, operación desarrollada antes por científicos y militares.

Por otra parte, la excursión de Anchorena no es ni científica, ni militar sino una cacería, él es un cazador que repite el viaje que previamente hicieron militares y naturalistas.

A pesar de su cuidada organización cronológica de las imágenes en relación al avance de la excursión, la primera foto citada en el texto no es la imagen de la partida («figura 1» de esa obra) sino la correspondiente a la «figura 29». Se trata de una curiosa escena donde se ve a "Pampa», el perro de caza del autor, mordiendo el cuerpo muerto de un huemul que cuelga en un árbol luego de haber sido cazado por los expedicionarios. El epígrafe afirma «Pampa centinela del campamento» (lámina 2). El huemul fue uno de los animales más preciados durante la aventura de Anchorena.

Nada más hermoso ni pintoresco que en algunas de sus abras y al borde de algún torrente vea a los huemules acercarse tímidos y curiosos, inocentes, acercándose al peligro que les espera; - hermoso conjunto para un pincel, y que recuerda al viajero los parques artificiales de Richmond, al borde del Támesis. El huemul es un ciervo más pequeño que el europeo y se encuentra solamente en los Andes patagónicos; su especie es desconocida en los museos europeos (7).

Sobre esa fotografía se demuestra un interés especial pues, además de ubicar su cita en primer lugar, su imagen fue especialmente retocada. Tal es la intervención sufrida que no es posible establecer con claridad si se trata de una foto o un dibujo. Dadas estas características, la imagen parece tener un componente alegórico en relación con lo salvaje del territorio y la imposición en él de la ley inquebrantable del progreso, de la cultura blanca y externa (el perro es blanco y se llama Pampa) imponiéndose sobre lo local (representado en la figura del huemul muerto). La escena es muy distinta de la que evocó en el cazador, el parque de Richmond.

Las fotos de Anchorena se cargan de un tono dramático particular al combinar en su secuencia el paisaje, la cacería y los grupos indígenas que el viajero visitó en su recorrido. La combinatoria de los tres tópicos se desarrolla con elocuencia en una serie de quince fotos en la cual la imagen del perro "pampa» antes mencionada se ubica en el centro. La secuencia comienza con la panorámica «Un mallin (hondonada fértil) en la Serranía de los Muertos» (lámina 3) y concluye con «Cacique Kanquel y caza del huemul»(ver figura 4). Entre ambas imágenes, el recorrido fotográfico ha integrado, con paulatinos acercamientos, a los tres tópicos mencionados. En «Serranía de los muertos» los viajeros posan casi imperceptibles en lo amplio del plano. En «Cacique Kankel y caza de huemul» Anchorena y sus acompañantes posan junto al cacique con un huemul muerto a sus pies. Es la fotografía donde se realizó el mayor acercamiento a los cuerpos. En especial el del animal muerto, que con un visible orificio de bala en un costado y un ojo abierto parece mirar aún a la cámara. La cabeza del animal queda relativamente alineada en esa misma dirección con la mirada del cacique, mientras el cazador, portando su escopeta, fue ubicado hacia el cuarto trasero del huemul más cercano al orificio. El epígrafe reúne los 


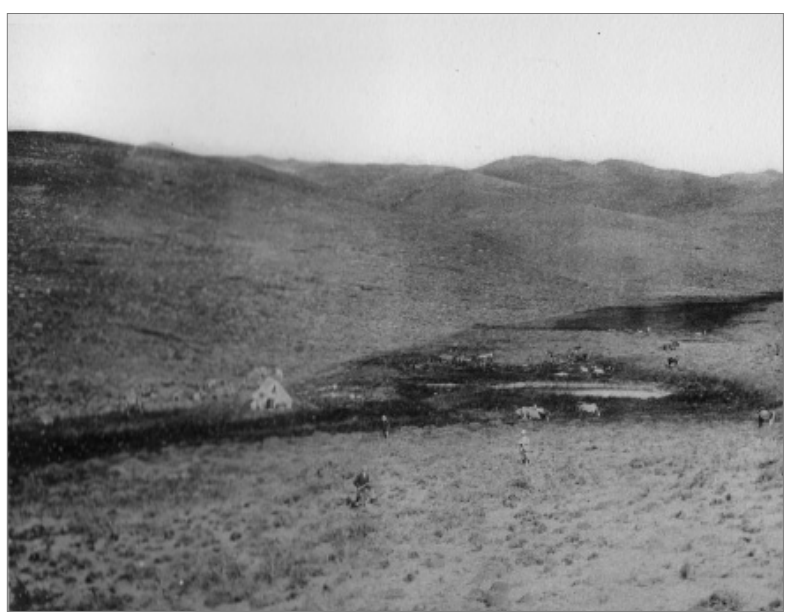

3. «Un mallin (hondonada fértil) en la Serranía de los Muertos». Excursión a la Patagonia y a los Andes (1902) de Aarón Anchorena.

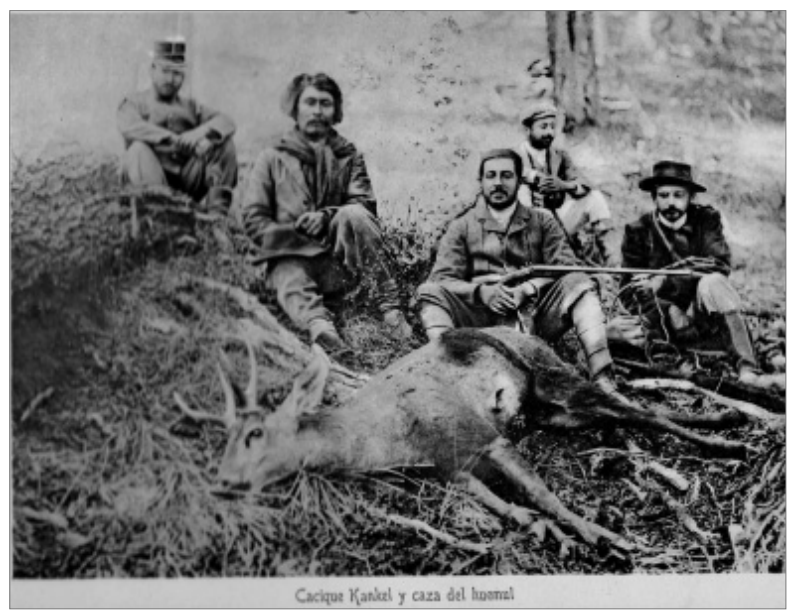

4. «Cacique Kankel y caza de huemul». Excursión a la Patagonia y a los Andes (1902) de Aarón Anchorena. 
dos tópicos exóticos: el indígena y la cacería del particular animal. La escena permite el desplazamiento de sentido entre muerte animal y la «extinción» indígena. Recordemos la sucesión de figuras retóricas antes citadas: «últimas reliquias que aún subsisten de las razas primitivas..., o que se extinguen gradualmente...». En la cacería de huemules en el Lago Fontana los expedicionarios ocupan dieciocho días, los que en el contexto del álbum se presentan como el momento de clímax de una secuencia cerrada por la descripta. Un poco más adelante otra imagen realiza un comentario suplementario o una coda a esa retórica de muerte y extinción. Anchorena cruzó en balsa el lago y en su otra orilla encontró un cementerio indígena. "Antiguo cementerio indígena en la península del lago Fontana», aclara el epígrafe de la foto que lo muestra sin su escopeta ante los montículos y en actitud reflexiva. A su lado, un soldado que oficiaba de ayudante posa con una pala sobre su hombro. El cacique ha desaparecido de la secuencia; se suma el cementerio y su explícita excavación (profanación); «extrajimos algunas curiosidades» (9), dirá el viajero (lámina 5).

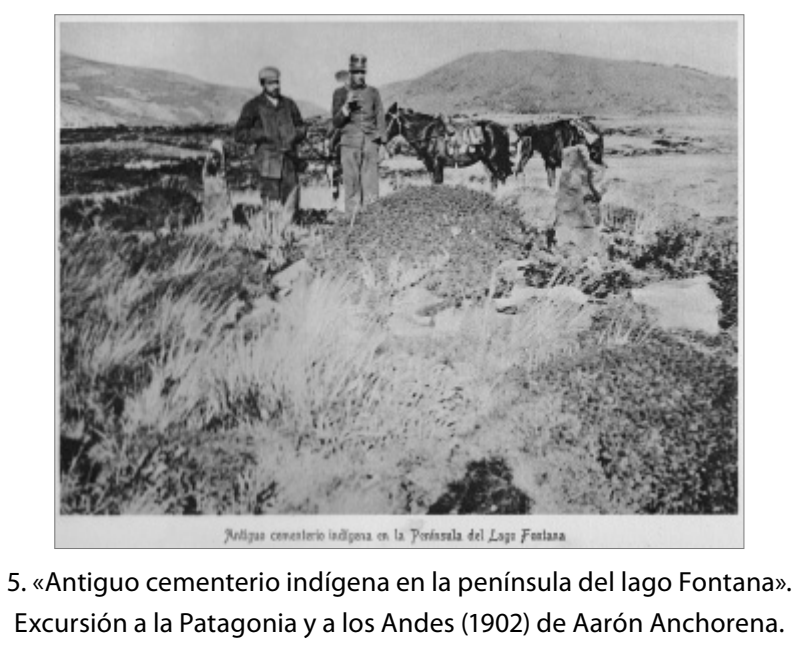

La práctica de cacería deportiva, como es sabido, no tiene fines prácticos fundados en el consumo o comercialización, se realiza sobre una reflexión de la relación de lo salvaje y lo doméstico. La Patagonia en el álbum de Anchorena se despliega entre esos términos. El mismo Enrique Hudson había dedicado un capítulo especial de sus «Días de ocio...» a la acción de los perros de caza importados en la región. Tal reflexión interviene en el paisaje, pues aquí es desarrollada en relación a los problemas de adaptación a la naturaleza local. Precisamente titula ese capítulo «Un perro exiliado».

\section{COMENTARIOS FINALES}

Con estos breves ingresos a las obras de Fontana y Anchorena y a sus antecedentes en la mirada del paisaje desierto es posible señalar que el entorno natural es incorporado por la fotografía como un telón de fondo de la acción civilizatoria nacionalista. Desde ella, 
desde su misma performance (el ritual militar, la toponimización y mitología geográfica nacionalista sobre el territorio, la cacería, y las poses correspondientes ante la cámara) el paisaje completa a su vez su sentido de representación, uso y contemplación. El cartel del Museo Leleque continúa con algo de esa tradición, como insistiendo en un paisaje que se enuncia desde lo arcaico a punto de desaparecer o con deseos de que desaparezca definitivamente.

En «El perro exiliado» Hudson describió a un perro inglés viejo y enfermo al que le da su confianza durante sus salidas de cacería. En la primera oportunidad su desempeño es magnífico: cruza un difícil pantano en búsqueda de un gran flamenco que el escritor había derribado con su escopeta. Posteriormente, en una situación similar ante un grupo de aves recién baleadas, el animal las reunió prolijamente en un islote del pantano para después divertirse despedazándolas. El perro domesticado conservaba oculta su otra naturaleza que le impulsaba a «la reversión súbita al perro salvaje» (76). La Patagonia fue construida con esa recurrente figura, incluso hoy se publicita como un territorio del «turismo aventura». El paisaje no solo interviene en la composición en la conversión del espacio en territorio civilizado y nacional, también en una topología simbólica. En ella el paisaje desierto produce un reflejo invertido donde es posible constatar la «verdadera» orientación de las cosas y el mundo.

\section{REFERENCIA}

Amigo, Roberto. (1994). Imágenes para una Nación. Juan Manuel Blanes y la pintura de tema histórico en la Argentina. Arte, Historia e Identidad en América Latina. México: IIE-UNAM.

Andermann, Jens. (2000). Mapas de Poder. Buenos Aires: Ed. Beatriz Viterbo.

Anderson, Benedict. (1993). Comunidades imaginadas. México: Fondo de Cultura Económica.

Anchorena, Aarón. (1902). Excursión a la Patagonia y a los Andes. Buenos Aires: Compañía Sud-Americana de Billetes de Banco.

Blengino, Van. (2005). La zanja de la Patagonia. Los nuevos conquistadores: militares, científicos, sacerdotes y escritores. Buenos Aires: Fondo de Cultura Económica.

Comaroff, John y Jean Comaroff. (1992). Ethnography and the Historical Imagination. Boulder: Westview Press.

Cosgrove, Denis. (2002). Observando la naturaleza: el paisaje y el sentido europeo de la vista. Boletín de la A.G.E 34: 63-89. Obtenido el 10 de noviembre de 2007 desde <http://www.ieg.csic.es/age/boletin/34/3406.pdf>.

Darwin, Charles. (2002). Voyage of the Beagle. Nueva York: Dover Publications.

Fitter, Chris. (1995). Poetry, space, landscape. Nueva York: Cambridge University Press.

Fontana, Luis J. (1976). Viaje de exploración en la Patagonia austral [1885]. Buenos Aires: Marymar.

Foucault Michel. (1991). El nacimiento de la clínica. Una arqueología de la mirada médica. Buenos Aires: Siglo XIX. 
Hirsch, Eric. (1995). Introduction. Landscape: Betwenn Place and Space. En Hirsch, Eric y Michael O’Hanlon (ed.) The Anthropology of landscape. Perspectivas on Place and Space (pp 5-30). Oxford: Clarendon Press.

Livon-Grosman Ernesto. (2003). Geografías imaginarias. El relato de viaje y la construcción del espacio patagónico. Buenos Aires: Ed. Beatriz Viterbo.

Masotta, Carlos. (2006). Imágenes recientes de la Conquista del Desierto. Problemas de la memoria en la impugnación de un mito de origen. Revista Runa 26: 225-245. Facultad de Filosofía y Letras-UBA.

- (2009). Frankenstein en la Patagonia. Imaginación arqueológica y territorio en las primeras fotografías de la región. Actas de las VII Jornadas de Arqueología de la Patagonia. (En prensa).

Moreno, Francisco. (1969). Viaje a la Patagonia Austral 1876-1877 [1879]. Buenos Aires: Solar/Hachette.

Navarro Floria, Pedro. (2006). Paisajes del progreso. La norpatagonia en el discurso científico y político argentino de fines del siglo XIX y principios del XX. Scripta Nova, Revista Electrónica de Geografía y Ciencias Sociales Universidad de Barcelona. Vol. X, 218: 76.1 de agosto. Obtenido el 4 de junio de 2007 desde <http://www. ub.es/geocrit/sn/sn-218-76.htm>.

Penhos Marta. (2005). Ver, conocer, dominar. Imágenes de Sudamérica a fines del siglo XVIII. Buenos Aires: Siglo XXI.

Pratt, Mary Louise. (1997). Ojos Imperiales. Literatura de viajes y transculturación. Bernal: Universidad Nacional de Quilmes.

Said, Edward. (1990). Orientalismo. Madrid: Libertarias.

Schama, Simon. (1996). Landscape and Memory. Londres: Harper Collins.

Silvestri Graciela y Fernando Aliata. (2001). El paisaje como cifra de armonía. Buenos Aires: Nueva Visión.

Tell, Verónica. (2001). La Toma del Desierto. Sobre la auto-referencialidad fotográfica. Poderes de la imagen, I Congreso Internacional de Teoría e Historia de las Artes. Buenos Aires: CAIA.

Vezub, Julio. (2002). Indios y soldados. Las fotografías de Carlos Encina y Edgardo Moreno durante la «Conquista del Desierto». Buenos Aires: El elefante Blanco.

Recepción: julio de 2009 Aceptación: octubre de 2009 